\title{
Identifikasi Ciri Garis Telapak Tangan Berbasis Template Matching dan Metode $K$ - Nearest Neighbor
}

\author{
ASEP NANA HERMANA, IRMA AMELIA DEWI, IRWAN SUSANTO
}

Institut Teknologi Nasional Bandung

Email : asep_nana_h@yahoo.com

\begin{abstract}
ABSTRAK
Telapak tangan merupakan ciri unik yang dimiliki oleh manusia yang dapat digunakan pada sistem identifikasi. Proses template matching membutuhkan perhitungan pencocokan untuk menentukan bagian kecil gambar yang memiliki nilai terbesar dikarenakan semakin besar nilai maka tingkat kecocokan semakin tinggi. Sehingga untuk pencocokan dibutuhkan perhitungan normalized cross correlation dengan perhitungan konvolusi yang setiap bagian pixel akan dilakukan pencocokan, diawali dari pixel bagian pojok kiri atas hingga pojok kanan bawah dan akan mendapatkan nilai pencocokan terbesar.Setelah mendapat nilai terbesar dilakukan k-nearest neighbor yang merupakan pengelompokan berdasarkan jarak dan untuk menentukan jarak $k$ digunakan perhitungan euclidien distance. Selanjutnya pengelompokan berdasarkan voting terbanyak yang dimulai dari nilai jarak ketetanggaan terkecil hingga terbesar. Tingkat akurasi pengujian dari 30 sampel telapak tangan didapatkan presentase sebesar $86,67 \%$ teridentifikasi benar dan 13,33\% salah.
\end{abstract}

Kata kunci : Telapak tangan, Template matching, K-nearest neighbor.

\begin{abstract}
Palms is unique to that of humans that can be used in the identification system. The process of matching template matching requires the calculation to determine the small section image which has the greatest value because the greater the value, the higher the degree of fit. So the normalized calculation required for matching cross colleration with convolution calculation that each pixel section will be matching, starting from the top left corner pixel to the lower right corner and will get the biggest match value. After receiving the greatest value do k-nearest neighbor which are groupings based the distance and to determine the distance $k$ used euclidien distance calculation. Further breakdown by voting majority that starts at a distance of neighborhoods smallest to largest. The level of accuracy of the testing of 30 samples of palms obtained a percentage of $86.67 \%$ and $13.33 \%$ identified the correct one.
\end{abstract}

Keyword : Palms, Template Matching, K-nearest neighbor. 


\section{Pendahuluan}

Telapak tangan merupakan ciri unik yang dimiliki oleh manusia. Telapak tangan memiliki ciriciri geometri yaitu lebar, panjang, dan area telapak tangan yang memiliki garis-garis prinsip seperti garis hati yang berada pada bagian bawah telapak tangan, garis kepala yang berada pada antara garis hati dan garis kehidupan, garis kusut yang berada pada posisi melintang antara garis hati, garis kepala, garis kehidupan dan garis kehidupan yang berada pada bagian atas telapak tangan.

Dengan adanya keunikan pada telapak tangan, maka telapak tangan dapat diimplementasikan dalam bidang pendidikan maupun bidang pekerjaan yang dapat difungsikan pada aplikasi presensi. Sistem identifikasi ciri garis telapak tangan memiliki dua proses yaitu proses pencocokan dengan template matching dan proses klasifikasi dengan $k$-nearest neighbor. Proses pencocokan menggunakan template matching yang bertujuan untuk menemukan bagian kecil yang diambil dari gambar yang yang sama dengan template gambar untuk mendapatkan nilai pixel template tertinggi. Pada pencocokan bagian-bagian kecil dari gambar digunakan perhitungan normalized cross correlation dengan cara perhitungan konvolusi. Metode $k$-nearest neighbor digunakan untuk proses klasifikasi dengan mengelompokan hasil pencocokan dengan menggunakan perhitungan jarak menggunakan euclidean distance. Selanjutnya mengurutkan berdasarkan nilai jarak terendah untuk urutan teratas hingga nilai jarak tertinggi untuk urutan terbawah. Kemudian akan diklasifikasi menggunakan voting terbanyak berdasarkan nilai ketetanggaan $(k)$.

Sistem ini dibuat dengan data masukan berupa gambar garis telapak tangan, data pengambilan citra garis telapak tangan dilakukan dengan posisi tangan dalam kondisi tegak $90^{\circ}$, jarak pengambilan data latih yaitu $5 \mathrm{~cm}$ dari kamera dan data uji yaitu $6 \mathrm{~cm}$ hingga 25 $\mathrm{cm}$ dari kamera dan sistem akan menghasilkan identifikasi berupa identitas kepemilikan garis telapak tangan.

\section{Analisis dan Metode}

Pada sistem identifikasi ciri garis telapak tangan memiliki dua proses pada saat melakukan identifikasi yaitu proses pecocokan dan proses klasifikasi. Hasil akhir sistem identifikasi diimplementasikan sebagai sistem presensi berupa identitas kepemilikan ciri garis telapak tangan. Pada Gambar 1 dapat dilihat gambaran dari proses kerja sistem secara keseluruhan.

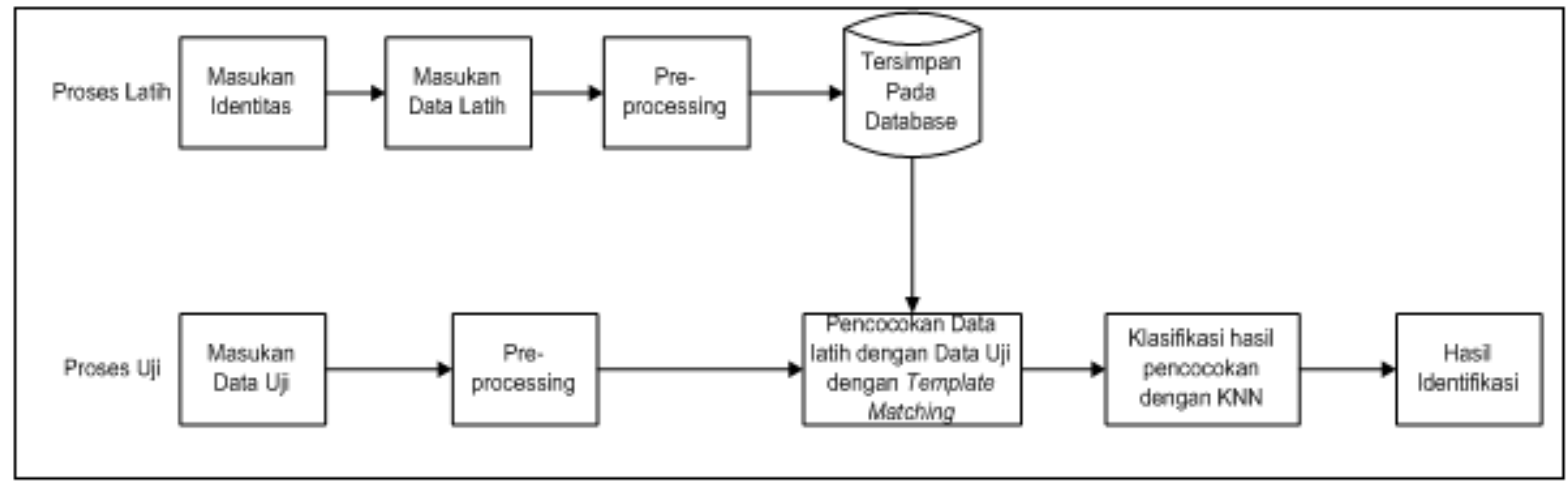

Gambar 1. Block diagram sistem

Proses pencocokan dilakukan dengan menggunakan metode template matching untuk menemukan bagian-bagian kecil dari gambar yang cocok dengan template gambar. Dalam 
teknik template matching dibutuhkan proses pencocokan untuk mengukur nilai pixel template uji dengan melakukan perhitungan mean dengan Persamaan 1 dan Persamaan 2.

$$
\begin{gathered}
\bar{f}=\frac{f_{1}+f_{2}+\ldots+f_{n}}{n_{f}} \\
\bar{g}=\frac{g_{1}+g_{2}+\ldots+g_{n}}{n_{g}}
\end{gathered}
$$

Dimana:

$\bar{f}=$ Rata-rata citra latih

$\bar{g}=$ Rata-rata citra uji

$n_{f}=$ Jumlah pixe/ citra latih

$f_{n}=$ Nilai pixe/ citra latih ke-n

$n_{g}=$ Jumlah pixe/citra uji

$f_{g}=$ Nilai pixe/ citra uji ke-n

Untuk mendapatkan nilai pixe/ kedua citra maka dilakukan proses standar deviasi dengan Persamaan 3 dan Persamaan 4.

$$
\begin{aligned}
& \hat{f}=\sqrt{\sum(f-\bar{f})^{2}} \\
& \hat{g}=\sqrt{\sum(g-\bar{g})^{2}}
\end{aligned}
$$

Dimana:

$\bar{f}=$ Standar deviasi citra latih

$\bar{g}=$ Standar deviasi citra uji

Untuk mendapatkan nilai citra baru maka dilakukan proses normalisasi dengan Persamaan 5 dan Persamaan 6.

$$
\begin{aligned}
& f(n, m)=\frac{f-\bar{f}}{\hat{f}} \\
& g(i, j)=\frac{g-\bar{g}}{\hat{g}}
\end{aligned}
$$

Dimana:

$f(n . m)=$ Citra latih ternomalisasi

$f \quad=$ Rata-rata citra latih

$g(n \cdot m)=$ Citra Uji ternomalisasi

${ }^{\prime} f \quad=$ Standar deviasi citra latih

$\bar{g} \quad=$ Rata-rata citra uji

$\hat{g} \quad=$ Standar deviasi citra uji

Proses perhitungan konvolusi yaitu proses dimana citra dimanipulasi dengan menggunakan subwindows untuk menghasilkan citra baru dengan perhitungan yang dimulai dari pojok kiri atas pixeltemplate uji hingga pojok kanan bawah pixeltemplate uji dan untuk perhitungan konvolusi digunakan perhitungan normalized cross correlation. Seperti pada persamaan 7.Maka apabila nilai pixel template uji yang didapat semakin besar maka tingkat kecocokan semakin tinggi dengan pixel template latih.

$$
N C C=\sum g(i, j) f(n, m)
$$


K-nearest neighbor adalah proses klasifikasi dengan mengelompokan kepemilikan data latih yang telah dilakukan proses pencocokan dengan menggunakan perhitungan jarak menggunakan euclidean distance sesuai dengan Persamaan 8.

$$
D(a, b)=\sqrt{\sum_{k=1}^{d}\left(a_{k}-b_{k}\right)^{2}}
$$

Dimana:

$a$ dan $b=$ Titik pada ruang vektor $\mathrm{n}$

$a_{k}=$ Rata-rata nilai citra latih

$b_{k}=$ Rata-rata nilai citra ujis

Hasil dari perhitungan jarak maka akan diurutkan berdasarkan nilai jarak terendah untuk urutan teratas hingga nilai jarak tertinggi untuk urutan terbawah kemudian akan diklasifikasi menggunakan voting terbanyak berdasarkan nilai ketetanggaan $(k)$ yang ditentukan berdasarkan nilai kelipatan ganjil yaitu 1,3,5,7,9,dst. Maka sistem akan menghasilkan identitas kepemilikan ciri garis telapak tangan.

\section{PEMBAHASAN DAN PENGUJIAN}

Sistem identifikasi ciri garis telapak tangan mempunyai 2 proses yaitu proses tahap latih dan proses tahap uji.

\section{Proses Tahap Latih}

Pada proses ini berguna untuk menyimpan sampel data garis telapak tangan. Proses untuk tahap latih adalah sebagai berikut.

a. Tahap awal masukan citra latih yang memiliki format (.jpg) dengan nilai pixe/ sample 200x200. Contoh pixe/ untuk citra latih dengan ukuran pixe/ $3 \times 3$ seperti pada Gambar 2, dengan nilai pixel sebagai berikut (2903, 2502, 2201, 2200, 2451, 2305, 2202, 2552, 2510)

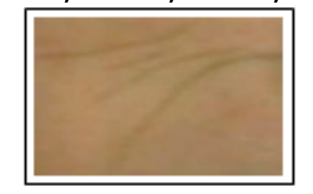

\section{Gambar 2. Citra Latih}

b. Untuk melakukan proses pencocokan, citra latih dilakukan proses grayscaling dengan menggunakan persamaan 9 .

Luminosity $=(\mathrm{R} \times 0.21)+(\mathrm{G} \times 0.75)+(\mathrm{B} \times 0.07)$

Maka dapat diketahui nilai pixe/ citra latihseperti pada Gambar 3.

\begin{tabular}{|l|l|l|}
\hline 2903 & 2502 & 2201 \\
\hline 2200 & 2451 & 2305 \\
\hline 2202 & 2552 & 2510 \\
\hline
\end{tabular}

Gambar 3. Nilai pixe/latih 
Menggeser bit dilakukan untuk mendapatkan nilai RGB didapat dengan. Proses pergeseran bit dilakukan dengan cara sebagai berikut.

$\mathrm{R}=(\mathrm{px}>>16$ bit $) \& 255$

$\mathrm{G}=(\mathrm{px}>>8$ bit $) \& 255$

$B=(p x \& 255)$

Dan akan menghasilkan pengkonversian matriks RGB seperti pada Gambar 4.

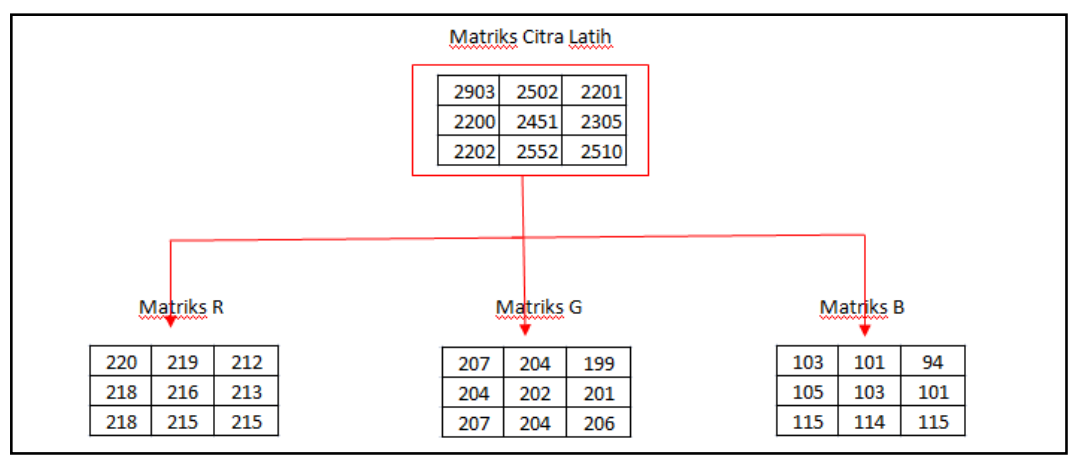

Gambar 4. Konversi RGB

Proses perhitungan grayscaling dimulai dari pixel $(0,0)$ hingga pixel $(2,2)$ dengan contoh perhitungan yang diketahui untuk pixel $(0,0) R=220, G=207, B=103$, sebagai berikut. $\mathrm{s}(0,0)=(0.21 * 220)+(0.72 * 207)+(0.07 * 103)$

$=35+24,9+10,1$

$=70$

Nilai grayscale untuk citra latih sebagai berikut $(70,90,85,83,90,85,60,75,75)$.

C. Hasil dari proses grayscaling yang didapat yaitu suatu sampel latih yang akan disimpan pada databasedengan nilai pixel dan digunakan sebagai bahan referensi untuk pencocokan data uji dan data latih dalam proses pengidentifikasian identitas menggunakan garis telapak tangan.

\section{Proses Tahap Uji}

Pada proses ini dilakukan pencocokan dan pengklasifikasian terhadap citramasukan. Proses untuk citra uji adalah sebagai berikut:

a. Tahap awal citra uji didapatkan dari proses masukan keseluruhan telapak tangan. Citra tersebut memiliki format (.jpg) dengan nilai pixel $800 \times 800$. Contoh nilai pixe/ untuk citra uji dengan ukuran pixe/ $9 \times 9$ sebagai berikut : $(200,205,205,178,130,198,189,200$, $201,197,181,193,186,200,165,176,199,193,183,194,179,187,164,165,190,200$, $203,154,200,162,135,135,190,183,163,160,176,203,150,135,136,187,193,182$, $171,187,204,155,160,140,189,192,176,181,190,201,194,198,205,173,154,186$, 207, 188, 187, 199, 156, 197, 203, 179, 183, 164, 173, 183, 191, 200, 201, 198), dengan masukan citra uji seperti pada Gambar 5.

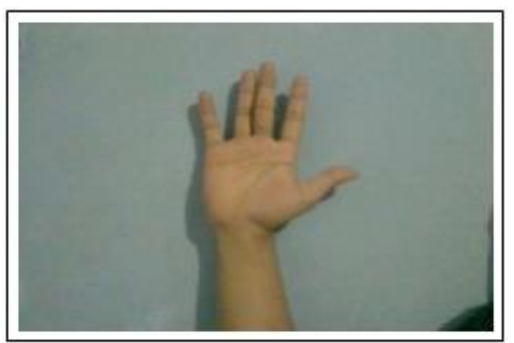

Gambar 5. Citra Uji 
b. Nilai pixel dari citra masukandicocokan dengan database yang sebelumnya telah tersimpan. Pencocokan digunakan dengan menggunakan template matchingdidapatkan nilai maximumseperti dapat dilihat pada Gambar 6.

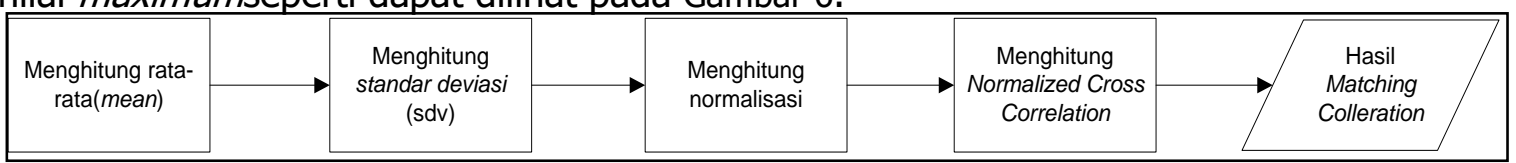

Gambar 6. Template Matching

Adapun penjelasan dari proses template matching sebagai berikut.

1. Mean adalah menghitung rata-rata dari seluruh pixe/ dari citra. Perhitungan rata-rata ini digunakan untuk menghitung proses normalisasi dari citra, dimana dilakukan untuk pixel citra latih dan pixe/ citra uji. Seperti pada persamaan 1 dan persamaan 2. Untuk menghitung nilai rata-rata citra latih sebagai berikut.

$\bar{f}=\frac{70+90+85+83+90+85+60+75+75}{9}$, maka akan menghasilkan nilai yaitu 79,22.

Perhitungan rata-rata pada citra uji sebagai berikut.

$200+205+205+178+130+198+189+200+201+190+197+181+193+186+200+165+$

$176+199+193+183+194+179+187+164+165+190+200+203+154+200+162+135+$

$135+190+183+163+160+176+203+150+135+136+187+193+182+171+187+204+$

$155+160+140+189+192+176+181+190+201+190+201+194+198+205+173+154+$

$186+207+188+187+199+156+197+203+179+183+164+173+183+191+200+201+$

$\bar{g}=\frac{198}{81}$

maka

akan menghasilkan nilai yaitu 182,11.

2. Standar deviasi dihitung dari kedua citra yang dianalisis. Untuk menghitung standar deviasi citra latih dimulai dari pixel $(0,0)$ hingga $(2,2)$ dengan contoh perhitungan pixel $(0,0)$ sebagai berikut.

$(70-79,22)^{2}=85,00$

Untuk perhitungan standar deviasi citra uji dimulai dari pixel $(0,0)$ hingga $(8,8)$ dengan contoh perhitungan pixe/ $(0,0)$ sebagai berikut.

$(200-182,11)^{2}=320$

Menghitung nilai standar deviasi untuk citra latih sebagai berikut.

$\bar{f}=\frac{85,00+116,2+33,40+14,28+116,2+33,40+369,4+17,80+17,80}{79,22}$

$$
=\sqrt{\frac{803,48}{79,22}}=\sqrt{10,14}=3,18
$$

Nilai standar deviasi untuk citra latih adalah 3,18 dan perhitungan nilai standar deviasi untuk citra uji sebagai berikut.

$320+523+523+16+212+252+27+320+325+62+221+1+118+15+320+292+37+$ $262+118+1+141+9+24+630+292+62+320+436+790+320+404+2219+2219+62+$ $1+365+488+373+399+1031+2219+2126+24+118+1+123+84+400+734+489+$ $-1773+47+97+37+1+62+356+62+356+141+252+523+82+790+15+619+34+24+$ $\bar{g}=\frac{285+681+221+436+9+1+327+82}{182,11}$

$$
=\sqrt{\frac{29194}{182,11}}=\sqrt{160,30}=12,66
$$

Maka nilai standar deviasi untuk citra uji adalah 12,66.

3. Normalisasi bertujuan untuk melakukan pembulatan nilai hasil standar deviasi dengan hasil yang mendekati nilai standar deviasi. Untuk melakukan perhitungan normalisasi pada citra latih dimulai dari pixel $(0,0)$ hingga pixel $(8,8)$ dengan contoh perhitunganpixel $(0,0)$ sebagai berikut. 
$(70-79,22) / 3,18=-3$

Maka menghasilkan nilai normalisasi citra latih yaitu $(-3,-3,-2,-1,-3,-2,-6,-1,-1)$. Perhitungan normalisasi pada citra uji dimulai dari pixel $(0,0)$ hingga pixel $(8,8)$ dengan contoh perhitungan pixe/ $(0,0)$ sebagai berikut:

$(200-182,11) / 12,66=1$

Maka menghasilkan nilai normalisasi citra uji yaitu $(1,2,2,-1,-1,1,1,1,1,1,1,-1,1,1,1$, $1,-1,1,1,1,1,-1,1,-1,-1,1,1,2,-2,1,-1,-4,-4,1,1,-1,-2,-1,2,-2,-4,-4,1,1,-1,-1$, $1,2,-2,-3,-3,1,1,-1,1,1,1,1,1,1,1,2,-1,-2,1,2,1,1,1,-2,1,2,-1,1,-1,-1,1,1,1$, $1,1)$.

4. Normalized cross correlation dilakukan untuk membandingkan nilai matriks citra uji dengan citra latih dari setiap pixehyadengan sistem perhitungan konvolusi yang dimulai pada pixe/ $(0,0)$ hingga pixe/ $(8,8)$ dengan contoh perhitungan pada pixel $(0,0)$ sebagai berikut:

$$
(-3 * 0)+(-3 * 0)+(-2 * 0)+(-1 * 0)+(-3 * 1)+(-2 * 2)+(-6 * 0)+(-1 * 1)+(-1 * 1)=-9
$$

5. Hasil dari proses template matching yaitu nilai pixel terbesar. Semakin besarnilai pada template maka tingkat kecocokan semakin tinggi dengan citra latih dan hasil untuk proses template matching seperti pada Gambar 7.

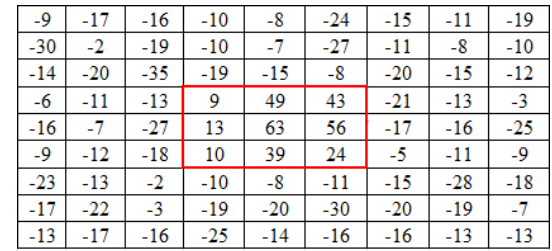

\section{Gambar 7.Hasil Matching}

$\frac{9+49+43+13+63+56+10+39+24}{9}=34$

c. Nilai rata-rata yang didapat pada proses template matching menjadi acuan untuk proses klasifikasi dengan menggunakan metode $K$-nearest (lihat gambar 8 ) yaitu pengelompokan data sesuai dengan nilai $\mathrm{K}$ yang telah ditentukan.

\begin{tabular}{|c|c|c|c|c|}
\hline $\begin{array}{c}\text { Tentukan } \\
\text { jumlah } \\
\text { tetangga } \\
\text { terdekat } \mathrm{K}\end{array}$ & $\rightarrow \begin{array}{c}\text { Hitung jarak tes } \\
\text { data ke training } \\
\text { data }\end{array}$ & $\begin{array}{c}\text { Urut data } \\
\text { berdasarkan data } \\
\text { yang mempunyai } \\
\text { jarak euclidien } \\
\text { terkecil }\end{array}$ & $\begin{array}{l}\text { Tentukan kelompok } \\
\text { tes data berdasarkan } \\
\text { label mayoritas pada } \\
\mathrm{K}\end{array}$ & $\begin{array}{c}\text { Hasil } \\
\text { Identifikasi }\end{array}$ \\
\hline
\end{tabular}

\section{Gambar 8.K-Nearest Neighbor}

Adapun penjelasan dari proses $k$-nearest neighbor sebagai berikut:

1. Penentuan tetangga terdekat $(k)$ antara sample latih dan hasil pencocokan dengan mengikuti ketetapan yang telah diterapkan yaitu dengan memilih nilai $(k)$ berdasarkan nilai kelipatan ganjil yaitu $1,3,5,7$,dst dan pada penelitian ini ditentukan nilai kelipatan yaitu 5 .

2. Perhitung jarak antara sample latih dan hasil pencocokanmenggunakanpersamaan 8 . Untuk melakukan perhitungan jarak dapat dilakukan seperti Tabel 1. 
Tabel 1. Perhitungan jarak

$\begin{array}{ccc}\text { Perhitungan } & \text { Urutan } & \text { Nama } \\ (79,22-34)^{2}=\sqrt{2044,8}=45,21 & 2 & \text { A1 } \\ (79,22-35)^{2}=\sqrt{1955,4}=44,21 & 1 & \text { A2 } \\ (79,22-33)^{2}=\sqrt{2136,2}=46,21 & 3 & \text { A3 } \\ (79,22-32)^{2}=\sqrt{2229,7}=47,21 & 5 & \text { B1 } \\ (79,22-31)^{2}=\sqrt{2325,1}=48,21 & 7 & \text { B2 }\end{array}$

3. Mengurutkan data yang mempunyai nilai $\mathrm{k}=5$.

4. Tahap mengelompokan sample latih berdasarkan mayoritas nilai $k$, seperti pada Tabel 2.

Tabel 2. Pengelompokan berdasarkan $k$

\begin{tabular}{|c|c|c|}
\hline \multicolumn{1}{|c}{ Nilai } & Urutan & Nama \\
\hline 44,21 & 1 & $\mathrm{~A} 2$ \\
\hline 45,21 & 2 & $\mathrm{~A} 1$ \\
\hline 46,21 & 3 & $\mathrm{~A} 3$ \\
\hline 46,21 & 4 & $\mathrm{C} 1$ \\
\hline 47,21 & 5 & $\mathrm{~B} 1$ \\
\hline
\end{tabular}

d. Hasil dari pencocokan yang didapat yaitu berupa nama kepemilikan ciri garis telapak tangan.

\section{Pengujian Sistem}

Pada aplikasi identifikasi ciri garis telapak tangan dilakukan uji fungsi (blackbox) dan dilakukan uji alpha. Pengujian dilakukan pada 30 sampel yang diuji dengan 12 data latih dengan kondisi berbeda, dimana kondisinya adalah sebagai berikut:
a) kering, 10 lux, $90^{\circ}$
g) basah, 10 lux, $90^{\circ}$
b) kering, 50 lux, $90^{\circ}$
h) basah, 50 lux, $90^{\circ}$
c) kering, 10 lux, $40^{\circ}$
i) basah, 10 lux, $40^{\circ}$
d) kering, 50 lux $40^{\circ}$
j) basah, $50 \operatorname{lux}, 40^{\circ}$
e) kering, 10 lux, $130^{\circ}$
k) basah, 10 lux, $130^{\circ}$
f) kering, 50 lux, $130^{\circ}$
l) basah, 50 lux, $130^{\circ}$

Pengujian juga dilakukan untuk mengukur beberapa kondisi pada posisi telapak tangan, intensitas cahaya, jarak pengambilan data, kelembaban telapak tangan dan kondisi telapak tangan, seperti terlihat pada Gambar 9. 


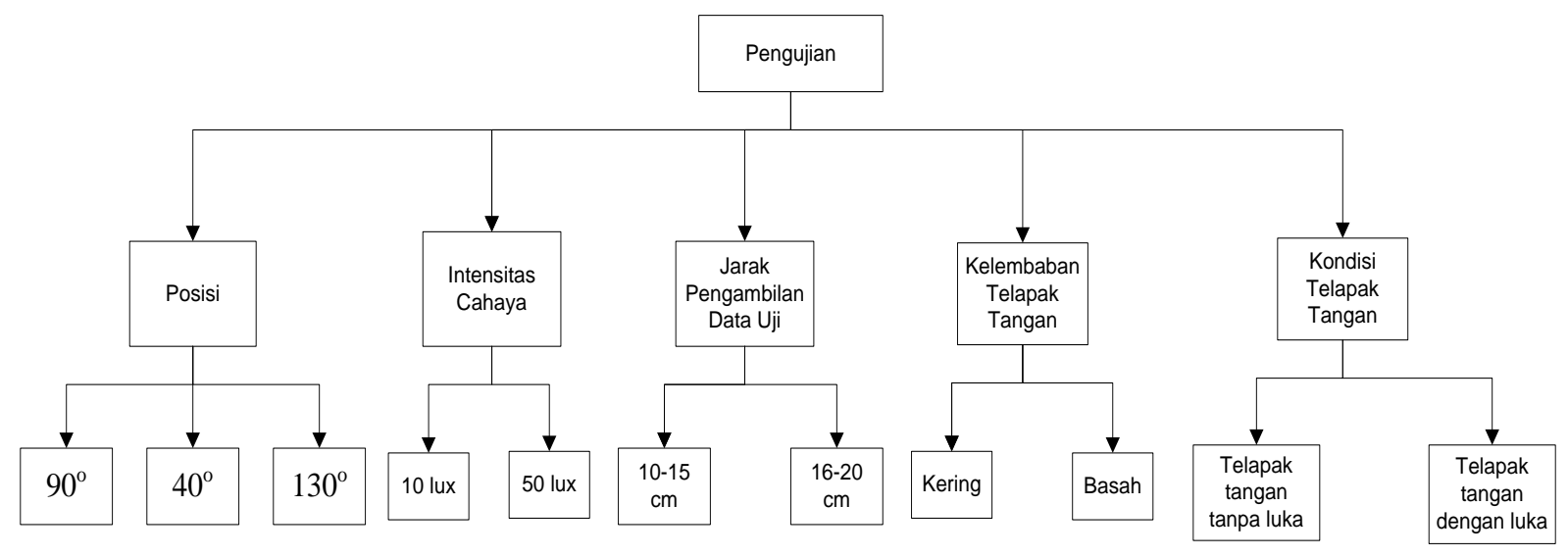

\section{Gambar 9. Skenario Pengujian}

Hasil dari pengujian kondisi posisi telapak tangan dengan posisi $90^{\circ}$ didapatkan presentase keberhasilan sebesar $87,88 \%$, untuk posisis $40^{\circ}$ didapatkan presentase keberhasilan sebesar $40,00 \%$ dan posisi $130^{\circ}$ didapatkan presentase keberhasilan sebesar 38,89\%, maka posisi telapak tangan optimal yaitu pada posisi $90^{\circ}$, rincian ada pada Tabel 3.

Tabel 3. Total Pengujian Posisi

\begin{tabular}{cccc} 
No & Pengujian Posisi & $\begin{array}{c}\text { Tingkat } \\
\text { Keberhasilan }\end{array}$ & Presentase \\
\hline 1 & Posisi $90^{\circ}$ & 79 pengujian & $\frac{79}{90} \times 100 \%=87,88 \%$ \\
2 & Posisi $40^{\circ}$ & 36 pengujian & $\frac{36}{90} \times 100 \%=40,00 \%$ \\
3 & Posisi $130^{\circ}$ & 35 pengujian & $\frac{35}{90} \times 100 \%=38,89 \%$ \\
\hline
\end{tabular}

Hasil dari pengujian kondisi intensitas cahaya dengan intensitas 10 lux didapatkan presentase keberhasilan sebesar $64,44 \%$ dan intensitas 50 lux didapatkan presentase keberhasilan sebesar $88,89 \%$, maka intensitas cahaya optimal yaitu intensitas cahaya 50 lux , rincian dapat dilihat pada Tabel 4 .

Tabel 4. Total Pengujian Intensitas Cahaya

\begin{tabular}{|cccc} 
No & Pengujian Intensitas Cahaya & $\begin{array}{c}\text { Tingkat } \\
\text { Keberhasilan }\end{array}$ & Presentase \\
\hline 1 & 10 Lux & 58 pengujian & $\frac{58}{90} \times 100 \%=64,44 \%$ \\
2 & 50 Lux & 80 pengujian & $\frac{80}{90} \times 100 \%=88,89 \%$ \\
\hline
\end{tabular}

Hasil dari pengujian jarak pengambilan data uji dengan jarak pengujian $10-15 \mathrm{~cm}$ didapatkan presentase keberhasilan sebesar 82,22\% dan jarak pengujian $16-20 \mathrm{~cm}$ didapatkan presentase keberhasilan sebesar $60,00 \%$, maka jarak uji optimal yaitu jarak 10 $15 \mathrm{~cm}$ (table 5). 
Tabel 5. Total Pengujian Jarak Uji

\begin{tabular}{cccc} 
No & Pengujian Jarak Uji & $\begin{array}{c}\text { Tingkat } \\
\text { Keberhasilan }\end{array}$ & Presentase \\
\hline 1 & $10-15 \mathrm{~cm}$ & 74 pengujian & $\frac{74}{90} \times 100 \%=82,22 \%$ \\
2 & $16-20 \mathrm{~cm}$ & 54 pengujian & $\frac{54}{90} \times 100 \%=60,00 \%$ \\
\hline
\end{tabular}

Hasil dari pengujian kondisi kelembaban telapak tangan dengan kelembaban kering mendapatkan presentase keberhasilan sebesar $84,44 \%$ dan kelembaban basah mendapatkan presentase keberhasilan $78,89 \%$, maka kelembaban telapak tangan optimal yaitu kelembaban telapak tangan kering, rincian dapat dilihat pada Tabel 6.

Tabel 6. Total Kelembaban Telapak Tangan

\begin{tabular}{cccc} 
No & Pengujian Kelembaban & $\begin{array}{c}\text { Tingkat } \\
\text { Keberhasilan }\end{array}$ & Presentase \\
\hline 1 & Kelembaban Kering(42\%) & 76 pengujian & $\frac{76}{90} \times 100 \%=84,44 \%$ \\
2 & Kelembaban Basah(46\%) & 71 pengujian & $\frac{71}{90} \times 100 \%=78,89 \%$.
\end{tabular}

Hasil dari pengujian kondisi telapak tangan dengan kondisi telapak tangan terdapat luka dan telapak tangan tanpa luka mendapatkan presentase sebesar $86,67 \%$, rincian dapat dilihat pada Tabel 7.

Tabel 7. Pengujian Kondisi Telapak tangan

\begin{tabular}{cccc} 
No & Nama Pengujian & $\begin{array}{c}\text { Tingkat } \\
\text { Keberhasilan }\end{array}$ & Tingkat Kesalahan \\
\hline 1 & $\begin{array}{c}\text { Pengujian Orang Tanpa } \\
\text { Luka }\end{array}$ & 13 orang & 2 orang \\
& Pengujian Orang Dengan & 13 orang & 2 orang \\
& Luka Pada Telapak Tangan & $\frac{26}{30} \times 100 \%$ & $\frac{4}{30} \times 100 \%$ \\
& Total Presentase & $=86,67 \%$ & $=13,33 \%$
\end{tabular}




\section{KESIMPULAN}

Dari Penelitian dapat disimpulkan bahwa untuk mengidentifikasi ciri garis telapak tangan didapat posisi optimal adalah $90^{\circ}$ dengan intensitas cahaya50 lux dimana jarak uji adalah $10 \mathrm{~cm}$ sampai dengan $15 \mathrm{~cm}$. Kelembaban telapak tangan yang dapat dideteksi yaitu kelembaban kering dengan kondisi telapak tangan tanpa luka. Presentase tingkat keberhasilan yang didapat sebesar $86,67 \%$. Hal tersebut terjadi karena beberapa faktor yaitu karakteristik garis telapak tangan yang tipis dan tingkat kemiripan garis telapak tangan yang hampir sama antar manusia.

\section{DAFTAR PUSTAKA}

Suriyanti. (2011),Identifikasi Telapak Tangan Dengan Ekstrasi Fitur Dimensi Fraktal dan Lacunarity. Surabaya : Sekolah Tinggi Teknik Surabaya.

Yuni Yamasari. (2013), Identifikasi Ciri Garis Telapak Tangan Berbasis Template Matching. Surabaya : Universitas Negeri Surabaya.

Deby Febriany, dkk. (2013), Identifikasi Individu Berdasarkan Pola Garis Tangan Dengan Menggunakan Metode Fractal Dan K-Nearest Neighbor. Bandung : Universitas Telkom.

Melly Arisandi, dkk. (2013), Sistem Pengenalan Berdasarkan Ciri Garis Telapak Tangan Menggunakan Metode Jaringan Saraf Tiruan Perambatan Balik. Semarang : Universitas Diponegoro.

Annaziat Jusuf. (2016), Aplikasi Deteksi Dini ADD Pada Anak Melalui Gerak Kepala Dan Media Game. Bandung : Institut Teknologi Nasional.

Setiawan, Heri. 2014. Implementasi Metode Normalized Cross Correlation Pada Template Matching Untuk Aplikasi Pendeteksi Objek Pada Citra Digital. Bandung : Universitas Komputer Indonesia.

Putri, Nadya Disya,et all. 2013. Klasifikasi Huruf Korea (Hangul) dengan Metode Template Matching Correlation. Malang: Universitas Brawijaya 